\title{
THE JAVANESE AS EMIGRANT: OBSERVATIONS ON THE DEVELOPMENT OF JAVANESE SETTLEMENTS OVERSEAS
}

\author{
Craig A. Lockard
}

Scholars interested in Indonesia are well aware of the phenomenon of Chinese emigration and settlement overseas, for the Overseas Chinese are an important component of the population in Indonesia as well as the rest of Southeast Asia. Yet few are aware that Indonesia itself has produced a sizeable emigrant population; until recently little has been written about the largest segment of this group, the Javanese. The pioneer research on Surinam by the Indo-

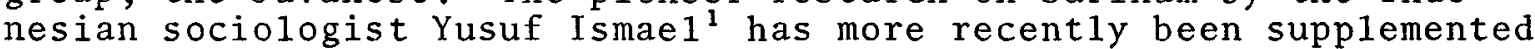
by the field studies of American anthropologists Annemarie de Waal Malefijt on Surinam and Alice G. Dewey on New Caledonia. ${ }^{2}$ As yet, however, no attempt has been made to analyze the various Javanese communities abroad, and the whole phenomenon of Javanese emigration, in comparative perspective.

The purpose of this essay is to draw together the divergent and still inconclusive data about Javanese emigration and three of the main areas of Javanese settlement overseas--Surinam, New Caledonia, and Malaya. This is largely an attempt to integrate and organize the existing material to provide a guide for further research. The essay considers the social and economic background to emigration, the emigration process itself, and the nature of Javanese society overseas.

Ascertaining the precise number of Javanese permanently settled outside of Indonesia today is difficult because of inconsistent census data. A probable estimate is that between 240,000 and 250,000 persons who cal1 themselves "Javanese" live outside the present Republic of Indonesia. Based on census reports that range from 1947 to 1963, the approximate Javanese population in the early

1. Yusuf Ismae1, "Indonesia" Pada Pantai Lautan Atlantik (Djakarta: Perpustakaan Perguruan Kementerian P.P. dan K, 1955); Yusuf Ismae 1, De Immigratie van Indonesiers in Suriname (Leiden: Luctor et Emergo, 1949); Yusuf Ismael, "De Indoneisische Bevolkingsgroep in Suriname," Mimeographed (Amsterdam: Stichting voor de Culturele Samenwerking, 1950).

2. Annemarie de Waal Malefijt, The Javanese of Surinam (Assen: van Gorcum, 1963). Alice G. Dewey, "The Noumea Javanese--An Urban Community in the South Pacific," South Pacific Bulletin, 14, no. 4 (October 1964), pp. 18-23, 26; "Restructuring Roles as a Strategy of Urban Adaptation," in Robert Van Niel, ed., Economic Factors in Southeast Asian Socia1 Change (Honolulu: Asian Studies Program, University of Hawaii, 1968), pp. 29-52; and "Ritua1 as a Mechanism for Urban Adaptation," Man, 5, no. 3 (September 1970), pp. 438-448. 
1960 's for the important centers of Javanese settlement for which figures are available is as follows: ${ }^{3}$

Malaya
North Borneo (Sabah)
Sarawak
Surinam
New Caledonia

Tota1

$$
\begin{array}{r}
190,000 \\
5,400 \\
2,400 \\
43,000 \\
3,600 \\
\hline 244,400
\end{array}
$$

The total does not include the few hundred Javanese who live in Brunei and Australian Papua and New Guinea, ${ }^{4}$ nor the 35,000 Cape Malays in South Africa, nor the nearly 26,000 "Malays" in Ceylon,

3. The term "Malaya" as used in the text includes both the old Federation of Malaya and the State of Singapore. The 1957 census for Malaya and the 1960 census for Sarawak and North Borneo did not break down the "Indonesian" category. Malaya's 1947 census was more complete and enumerated 187,755 Javanese, including a few in Christmas Island and the Cocos and Keeling Is Iands. M.V. Del Tufo, Malaya: Report on the 1947 Census of Population (Kuala Lumpur: Government Printing office), p. 74. As little immigration occurred after 1947 , it is probable that the Javanese population did not change dramatical1y and likely numbers between 180,000 and 200,000. For North Borneo, the 1960 census does note that the Javanese group was similar to the 5,361 recorded in 1951 . L.W. Jones, North Borneo: Report on the Census of Population Taken on 10th August 1960 (Kuching: Government Printing Office, 1962), p. 53 . The Indonesian population of Sarawak remained stable between 1947 and 1960 and its Javanese component was probably similar to 1947 , when 2,397 Javanese were recorded. J.L. Noakes, Sarawak and Brunei: A Report on the 1947 Population Census (Kuching: Government Printing office, 1950), p. 88. The 1959 Surinam census recorded 43,195 Indonesians, nearly al1 Javanese. Waal Malefijt, Javanese of Surinam, p. 24. The 1963 New Caledonia census enumerated 3,563 Indonesians, most of whom are Javanese. Analyses des resultats du recensement de la population, 2 Mai 1963 (Paris: Institut National de la Statistique et des Etudes Economiques, 1963), p. 17.

4. The 1947 Brunei census 1isted 237 Javanese. Noakes, Sarawak and Brunei, p. 88. Some 208 "Other Asians" (excluding Chinese) lived in Australian Papua and New Guinea in 1961, some of whom may be descendants of Javanese imported as laborers in 1889. Judith Tudor, ed., Pacific Islands Yearbook and Who's Who (Sidney: Pacific Publications, 1963), p. 309.

5. Considering that the literature on the Cape Malays generally attributes their origin to Java, it might seem appropriate to include them in this survey. Yet, while some are descendants of political exiles, most are descendants of slaves brought to the Cape from Java by the Dutch in the seventeenth and eighteenth centuries. Because the majority of slaves in Java were non-Javanese, fewer ethnic Javanese were probably included. In any case, the Malay slaves intermarried extensively with other groups in South Africa. For more information, see I.D. DuPlessis, The Cape Malays (Capetown: Mi1ler, 1947); I.D. DuPless is and C. A. Lückhoff, The Malay Quarter and its Peop1e (Capetown: Balkema, 1953); E. Hellman, A Handbook of Race Relations in South Africa (Capetown: Oxford, 1949); John S. Mayson, The Malays of Cape Town (Manchester: Ga1t, 1861). 
many of whom are reported to be of Javanese ancestry. Likewise, no attempt has been made to include the Javanese who, for whatever reason, today live in Europe, the Middle East, or the United States. More importantly, the total does not include the unknown number of Javanese in Thailand, Burma, and South Vietnam, for which no census figures enumerate Javanese.

The latter omission is particularly important since Thailand and Burma, along with Malaya, were major centers for the use of romusha labor by the Japanese during the Occupation. The question of the romusha laborers has not been adequately studied. Estimates of the number of Javanese forced laborers sent to various parts of Southeast Asia by the Japanese range from 200,000 to 300,000 of which as few as 70,000 may have survived the war. Only about 10,000 were repatriated to Java, and the fate of those remaining is largely unknown. ${ }^{8}$ Since the romusha was not accompanied by wife or children, some who survived the war may have married non-Javanese women and may have lost much of their identity as Javanese.

The Javanese emigration with which we are concerned took place largely between 1875 and 1940 . For some, the move would be temporary; for many it was permanent. As with the development of the large Javanese settlement on the East Coast of Sumatra, Javanese emigration to Surinam, New Caledonia, Malaya and elsewhere was intimately tied in with the contract labor or indenture system and the development of large-scale plantation or mining industries. In every case of Javanese emigration, the Javanese were only one of several immigrant groups to be used in the labor force. And without exception, a society characterized by what is generally called social and cultural pluralism developed, with the Javanese becoming merely one segment of a plural society. Because of the nature of the indentured labor system, a certain amount of exploitation and coercion was involved, and thus the system itself had a strong hand in defining the nature of Overseas Javanese society.

Emigration was not completely unknown to the prospective Javanese emigrant. Historically Java was part of an archipelago

6. H.E. Peries, Census of Ceylon 1953, 1 (Colombo: Government Printing Office, 1957), enumerates 25,464 Malays. The Ceylon Malays are descendants of Malays and Javanese who were stationed in Ceylon as soldiers, and of a lesser number who came as traders, in the eighteenth and rineteenth centuries. E.K. Cook, A Geography of Ceylon (Madras: Macmilian, 1931), pp. 273-274.

7. There is some evidence of Javanese in Thailand before World War II. Javanese gardeners were seen in Bangkok in the 1890's, and as many as 3,000 Javanese contract laborers may have been in the country in 1937. H. Warington Smyth, Five Years in Siam (London: John Murray, 1898), I, p. 14; Bruno Lasker, Asia on the Move (New York: Holt, 1945), p. 66. Few of the prewar indentured Javanese workers probably remained in Cochin-China. See fn. 13 below.

8. Virginia Thoms on, Labor Problems in Southeast Asia (New Haven: Yale University, 1947), pp. 10-13, 163, 243; M. A. Aziz, Japan's Colonialism and Indonesia (The Hague: Nijhoff, 1955), pp. 240242; Harry J. Benda, The Crescent and the Rising Sun (The Hague: van Hoeve, 1958), p. 269; W. F. Wertheim, Indonesian Society in Transition (The Hague: van Hoeve, 1964), pp. 263-264. 
world which did not recognize political boundaries in any tight sense as a special barrier to settlement, whether temporary or permanent. Consequently, Javanese were among the many "Malay" peoples who settled in various parts of the archipelago. As a result, many Malays in Malaya, Borneo, and elsewhere can trace their roots back to Java, often to such pasisir (coastal) communities as Surabaja. Over the years, these immigrants from Java have generally lost much of their distinctiveness and become Malay.

With the establishment of the British in the early nineteenth century in what became the Straits Settlements, official records began reporting the arrival of Javanese immigrants. In Singapore, for example, a Kampong Java had been established by 1836 on the coast just west of the Rochore River. The Javanese population of Singapore grew slowly from 38 in 1825 to 5,885 in 1881. Penang and Malacca recorded an "Indonesian" population of 4,683 in 1871 , of which the largest contingent was evidently Javanese. Little data is available on the origin, stability of residence, sex ratio, language and occupations of these Javanese immigrants although some sources suggest the presence of Javanese servants, sailors, small-scale planters and petty traders in the $1880^{\prime} \mathrm{s}$ and $1890^{\prime} \mathrm{s}$. While these figures do not indicate a large-scale emigration from Java, they do suggest that some free emigration was in existence prior to the introduction of indentured 1abor. ${ }^{9}$

Javanese mobility began to grow in the late nineteenth century; by this time, conditions in rural Java were becoming difficult enough to provide a solid "push" for potential emigration, temporary or permanent, in search of a better 1ife. The deteriorating economic and ecological situation afflicting Java by the late nineteenth century, so wel1 described by Clifford Geertz, ${ }^{\circ}$ was characterized by population explosion, poverty, and land scarcity. The whole Javanese social structure became more fluid. By 1930, 4,500,000 Javanese lived outside the district where they were born, 11 and $1,200,000$, or 2.9 percent of a11 Javanese, lived outside of Java. ${ }^{12}$

Even with strong "push" factors, however, the Javanese was not an enthusiastic emigrant. The relative failure of Dutch-sponsored transmigration schemes to nearby Sumatra until well into the 1930 's

9. See R.W. Hodder, "Racial Groupings in Singapore," Malayan Journal of Tropical Geography, 1 (October 1953), p. 27; Tunku Shamsul Bahrin, "The Growth and Distribution of the Indonesian Population in Malaya," Bijdragen Tot de Taa1-, Land-en Volkenkunde, 123, no. 2 (1967), pp. 269-271; J. Norman Parmer, Colonial Labor Policy and Administration (Locust Valley, N.Y.: Augustin, 1960), p. 108 .

10. Clifford Geertz, Agricultural Involution (Berkeley: University of California, 1966).

11. Joachim Hurwitz, "Agricultural Resettlement of Javanese Farmers in the Outer Islands of Indonesia Before World War II," mimeo (Cambridge, Mass.: Center for International Studies, 1965), p. 21.

12. Soedigdo Hardjosudarmo, Kebidjaksanaan Transmigrasi Dalam Rangka Pembangunan Masjarakat Desa di Indonesia (Djakarta: Bhratara, 1963), p. 44. 
illustrates that the Javanese still had a reluctance to leave Java, even just to move across the channel to Lampung in southern Sumatra. The social ties of the village, of which attachment to the soil was but one factor, militated against leaving. Furthermore, most Javanese were inherently mistrustful of anything promoted by Europeans. There were also practical difficulties, such as a village headman opposing migration because of fear of losing his own revenue, or the shame which accrued to someone who deserted his family.

Just as emigration was not necessarily an unknown possibility for the increasingly desperate Javanese, so too was plantation and contract 1 abor not uncommon by the late nineteenth century. The growth of plantations on Java and Sumatra, engendered by the socalled "Liberal Policy" in the second half of the nineteenth century, relied on Javanese compelled to find work as wage-laborers on European-operated estates. The development of plantations in East Sumatra beginning in the $1860^{\prime}$ 's provided an even greater opportunity for Javanese laborers. Although Chinese were initially the most important element in the plantation labor force, Javanese by the thousands were soon being induced to sign contracts and migrate to East Sumatra, despite its notoriety for labor exploitation.

Many Javanese thus had some exposure to contract and estate labor, and the setting was developed for the beginning of emigration, both temporary and permanent, to Malaya, Surinam and New Caledonia, as well as British North Borneo, Sarawak and Cochin-China. ${ }^{13}$ Given the apparently easy accessibility of other labor sources such as China and India, it becomes necessary to explore the circumstances which led employers in these diverse outposts to recruit the Javanese. For in every case, other labor sources supplied a much larger number of indentured workers, and the Javanese were preceded by other Asian groups.

Malaya was the first territory to import Javanese labor and also the state to which the largest number of Javanese emigrated. Although thousands of Chinese were brought to Malaya to work in the tin mines, it was the expanding development of such export crops as sugar and coffee by the late nineteenth century and the growing interest in rubber by 1895 which brought Javanese laborers into Malaya. All three industries were largely under European control from the late nineteenth century onward.

13. British North Borneo, Sarawak and Cochin-China employed a significant number of Javanese laborers. North Borneo began importing Javanese in 1882 to augment Chinese labor on tobacco and other estates. Although turnover was high, immigration continued until World War II. Sarawak began recruiting Javanese in the 1880 's from Singapore; by 1902 , several thousand were working on several government-owned estates. Many settled permanently. Cochin-China began importing Javanese for estates in 1906 because of dissatisfaction with the Chinese. By 1930, immigration had ended and most Javanese had been repatriated. K. G. Tregonning, Under Chartered Company Rule (Singapore: University of Malaya, 1958 ), pp. 142-154; James C. Jackson, Sarawak (London: University of London, 1968), pp. 52, 89; Thompson, Labor

Problems, pp. 185-186; International Labor Office, Labour Conditions in French Indo-China (Geneva: 1938), pp. 249-250. 
The fact of European control partly explains the interest in Javanese labor. The bulk of the labor force in Malaya was Chinese and later Indian. But the Europeans feared dependence on Chinese labor and presumably wanted to keep their options open. The Chinese moreover, were thought to work better under the employ of their own countrymen and were seen as too inclined to take part in lawless secret societies. In any case, competition for the available Chinese labor was intense. Indian labor was quite desirable but competition for it was also strong. Malays were considered generally disinclined for estate work. Planters thus turned to Java for additional 1 abor supplies. The Javanese were in fact preferred by many European planters and civil servants because of the belief that they would more easily assimilate with the local Malay population. It was also thought that the Javanese were better suited for the clearing of jungle in the opening of estates because of the similarity of their home environment. ${ }^{14}$

Planters in Surinam (Dutch Guiana) also desired Javanese workers. Surinam's economy was based on sugar, cultivated first by African slaves and later by indentured Asian labor. In 1863 slavery was abolished, and few of the 33,000 ex-slaves chose to remain on the plantations. Because other sources of labor in the colony were unpromising, planters began to look overseas for a labor source. Several plans to recruit free 1 abor in Africa were evidently rejected, and the focus turned to Asia. Even before abolition, a few hundred Chinese and Portugese had been imported under indenture, although these workers proved unsatisfactory from the planters' viewpoint. Therefore the Dutch approached the British Government for permission to recruit in India; between 1873 and 1916, when the British Indian Government abolished recruitment for indentured labor, some 34,848 Indians entered the colony on five-year contracts. After some initial difficulties, they proved adequate workers, and the great majority elected to remain in Surinam permanently. ${ }^{15}$

Despite the apparent success of the Indian immigrants, an alternate labor source was being sought by the late $1880^{\prime} \mathrm{s}$. A major reason for this was the feeling on the part of many planters that an acute labor shortage still existed. Many Indians were said to have a difficult time adjusting to plantation 1ife. The Dutch also seem to have been concerned that the Indians, being British subjects, were not loyal to Dutch rule, and that Surinam was becoming too dependent on the British for labor. The Indians were theoretically protected by the British Consul in Paramaribo, and the planters desired the freer hand made possible by importing laborers who were also Dutch subjects. Because some Surinam planters had had experience in the East Indies

14. Parmer, Colonial Labor Policy, pp. 7-8, 108-109; Kernia1 Singh Sandhu, Indians in Malaya (Cambridge: University Press, 1969), pp. 54-57; Tunku Shamsul Bahrin, "Indonesian Labour in Malaya," Kajian Ekonomi Malaysia, 11, no. 2 (June 1965), pp. 59-60.

15. Rudolf van Lier, Samenleving in een Grensgebied ('s-Gravenhage: Nijhoff, 1949), pp.181-193. This is the main source on Surinam history. See also J. H. Adhin, Development Planning in Surinam in Historical Perspective (Leiden: Syenfert Kroese, 1961), Chapter 2; and J. D. Speckmann, "The Indian Group in the Segmented Society of Surinam," Caribbean Studies, 3, no. 1 (April 1963), pp. 3-17. 
and recommended the Javanese worker as "docile" and "even-tempered," and also because it was felt that costs of recruitment and maintenance would be less for workers imported from the Dutch East Indies, planters turned their attention to Java. The planters believed that the Dutch government might aid them in recruitment and transportation. 16

Unlike Malaya and Surinam, New Caledonia needed labor for both mining and.agriculture. New Caledonia was annexed by the French government in 1853 and became a penal colony. When nickel was discovered in 1870, European convicts provided the first labor force. The mining industry was largely controlled by one monopolistic firm. By 1890 more and more European immigrants were establishing sma11holdings and small estates, with coffee the most important crop. These planters preferred to import labor since the Melanesian inhabitants of New Caledonia were considered wholly unreliable because of their tendency toward rebellion against the colonial government, with whom relations were never better than a modus vivendi. In 1898 penal transportation was terminated, and the government was forced to look elsewhere for 1abor. In 1889, a group of 166 Chinese 1 aborers had been imported under five-year contracts, and in 1892 came 600 Japanese. The latter were not considered by the company to be "docile" enough and were subsequently repatriated. In 1900 another 1,000 Japanese were brought in, but many escaped and others went on strike. The Japanese, and the commercially-minded Chinese, had proved unsuitable as immigrant miners. Meanwhile, in 1891, 768 Vietnamese, mostly Tonkinese, had been recruited, beginning a labor importation that would continue until World War II.

By 1902 the demand for workers forced the mining officials to turn to sources other than Indochina, and in that year a contingent of 600 Indian Hindus from Pondicherry, and the first group of Javanese arrived in New Caledonia. It was too costly to import Indians in large numbers however. Other 1 abor sources were also not very promising. Without penal force, the Europeans, whether ex-convicts or recent immigrants, avoided heavy manual labor. The Melanesians were considered unreliable and at any rate they were closely tied to their land. Some workers from other islands, particularly the New Hebrides, were imported in the twentieth century but the available labor pool was not considered large enough. Java and Tonkin thus became the chief source of 1 abor for New Caledonia. ${ }^{17}$

16. Ismae1, Indonesia Pada Pantai, pp. 27-29; Ismae1, "De positie van de Indonesier in het niewe Suriname," Indonesië, 4 (19501951), pp. 179-180; Justus M. van der Kroef, "The Indonesian Minority in Surinam," American Sociological Review, 16, no. 5 (October 1951), p. 673. Actual1y, some thought was given to Javanese immigration to Surinam earlier in the century. In 1818 Johannes van den Bosch suggested sending Javanese criminals to Surinam. Later J. J. Rochussen, Minister of Colonies, advocated transferring whole villages from East Java to Surinam to grow rice. Neither idea obtained approval. S. Kalff, "Javanese Emigrants in Suriname," Inter-Ocean, 9, no. 10 (Óctober 1928), p. 547 .

17. Lewis Feuer, "End of Coolie Labor in New Caledonia," Far Eastern Survey, 15, no. 17 (August 28, 1946), p. 264; Jean Le Borgne, Geographie de la Nouvelle-Calédonie et des Iles Loyauté (Noumea: Ministére de l'Éducation, 1959), pp. 182-183, 255-259. 
Prospective labor recruiters faced various difficulties in gaining a work force from Java. The Government in general was reluctant to allow Javanese emigration outside of the Dutch East Indies, and an 1887 law explicitly prohibited Indonesians from working outside of the Indies. Opposition to emigration seems to have been a result of several factors. The Government claimed to fear that it would be powerless to prevent exploitation of the Javanese (a1though evidently exploitation in Sumatra was acceptable), and that it had insufficient staff to handle emigration. After 1900, many thought the outer Islands to be underpopulated and able to absorb Java's excess population. Perhaps the most important element was that European plantation owners and public works officials, especially in Sumatra, feared that their own labor market would be too constricted as they had difficulty enough recruiting in Java without foreign competition. ${ }^{18}$

The first government officially to request permission to recruit was that of Surinam. Initially the Indies'authorities were reluctant, but in 1890, perhaps because of pressure from both the Metropolitan and Surinam Governments, they agreed to allow recruitment of Javanese labor for Surinam on an experimental basis. In a scenario that would be repeated with later applicants, the Surinam Government was required to obtain permission annually from the Netherlands Indies' authorities and the emigration was to be closely regulated. ${ }^{9}$ In 1891 , the first group, 94 Javanese ( 61 men, 31 women and two children) sponsored by a private Dutch company, left Java for Paramaribo, where they were assigned to the Marienburg sugar estate. ${ }^{20}$

With Surinam thus setting the example, other governments followed over the next fifteen years; individual Malayan planters began active recruiting in Java in 1902 and New Caledonia negotiated an arrangement in the same year. In every case, Batavia authorities imposed stringent regulations on the recruitment, which was generally left to professional recruiters in Java. These regulations prompted a general sentiment among importers that Javanese labor was too expensive and that the Netherlands Indies Government was not sympathetic to Javanese emigration. 21 Nonetheless, Javanese workers continued to be sought and recruitment procedures were established.

The institution of the 1 abor recruiter in Java was critical to the procuring of emigrants. Although some laborers were recruited in Batavia, the center of recruiting activities was Semarang. Here

18. J. Heemstra, "De Indonesiers in Suriname," Indonesië, 6 (19521953), p. 431; Ismae1, Indonesia Pada Pantai, p. 39; A.D.A. de Kat Angelino, Colonial Policy (The Hague: Nijhoff, 1931), II, pp. 565566; Parmer, Colonial Labor, p. 110. There may also have been a general feeling that low wages, a main source of Java's wealth, would be threatened if foreigners were allowed to compete for what was considered a small labor pool. J. S. Furnivall, Netherlands India (Cambridge: University Press, 1939), p. 351.

19. Ismae1, "De positie van de Indonesier," p. 180; de Kat Angelino, Colonial Policy, II, pp. 265-266.

20. Ismae1, Indonesia Pada Pantai, pp. 29-30.

21. See, e.g., Parmer, Colonia1 Policy, pp. 108-110. 
there were both private recruiting firms and also recruiting offices set up by various planters from Sumatra, British North Borneo and Surinam. The private firms, usually operated by Europeans, obtained recruits for any party in return for a generally high commission. The field recruiters, generally Javanese, worked to obtain as many indentures as possible, regardless of methods. The recruiter (werak) was so thoroughly hated in Java that one branch of sarekat Is 2 am was said to require new members to swear that they "would not steal, would not recruit, and would not lie."22 Recruiters had to be licensed by the government. They exaggerated descriptions of 1 ife awaiting abroad, resorted to trickery, and connived with village headmen--anything to earn the 80 to 100 rupiah commission paid for each recruit. ${ }^{3}$

Mèdical examinations for all prospective emigrants were mandatory, and all contracts were supposed to be inspected by a Netherlands Indies officia1. But abuse was common. Recruits who had signed contracts were often locked up for months waiting for available passage. Despite health regulations which were allegedly stiffer than for labor going to Sumatra, there were still complaints, particularly in Malaya, that the Javanese were in poorer health than Chinese or Indians. This perhaps reflects the wretched conditions in the coolie depots. ${ }^{24}$

The reasons why an individual Javanese emigrated were a combination of compulsion and free initiative. K.0.L. Burridge reported that Javanese immigrants in Johore cited lack of cultivable 1 and and a desire to escape from "oppressive" Dutch rule as major reasons. ${ }^{5}$ Most emigrants were probably landless peasants, but "personal" factors were perhaps equally important. There is some evidence that a large number of Javanese emigrants to Surinam feared prosecution for criminal activity or sanctions for behavior which defied traditional norms. Some were fleeing family problems or military service. The devastation from the Gunung Merapi eruptions of 1930 spurred emigration as did a desire for success. And, of course, connivance or force by a recruiter were also factors. 26 , Wilfred Burchett reported meeting a Javanese woman in New Caledonia, working as a domestic servant, who claimed to have emigrated because her mother forced her to marry a man she disliked. ${ }^{27}$ In most cases, families could be taken along, so that many Javanese migrated with their wives, and often their children.

22. Willemina K1oosterboer, Involuntary Labour Since the Abolition of Slavery (Leiden: Bril1, 1960), p. 34 .

23. Ismae1, Indonesia Pada Pantai, pp. 39-41. See also Kloosterboer, Involuntary Labour, p. 34; de Kat Angelino, Colonial Policy, II, p. 568 .

24. See, e.g., Shamsul Bahrin, "Indonesian Labour," pp. 64-65.

25. Kenelm O.L. Burridge, "Racial Relations in Johore," Australian Journal of Politics and History, 11, No. 2 (May 1957), p. 153.

26. Ismae1, Indonesia Pada Pantai, pp. 41-42. Javanese laborers in Malaya complained that they had been tricked by recruiters. See Shamsu1 Bahrin, "Indonesian Labour," p. 64.

27. Wilfred Burchett, Pacific Treasure Island: ivew Caledonia (Philadelphia: McKay, 1941), pp. 80-82. 
Interestingly enough, many Javanese today, particularly among those in Surinam, will seldom admit to these reasons. Almost universally, always apologetically, the Surinam Javanese attribute their emigration to factors beyond their control. "Magic" is the most common reason given. The stories told today all involve recruitment taking place outside of the village by a stranger approaching the person when he was alone. Magic was used to make him forget his family, memory returning only when he was aboard ship. ${ }^{28}$ This has elements of self-justification, of course. The decision to emigrate, probably madè impulsively, was thought shameful, for it meant leaving one's family. Indeed, many Javanese claim to have given false names to the emigration authorities because they did not want their families to find out. ${ }^{29}$ Blame was transferred to an outside agent, in this case the recruiters. Whether Javanese in New Caledonia and Malaya report the same stories is unknown.

The magnitude of Javanese immigration differed from colony to colony. Between 1890 and 1939 some 32,956 Javanese emigrated to Surinam, the overwhelming majority as contract laborers. Nearly all came from Central Java. The peak years for Surinam immigration were from 1917 to 1928 , particularly 1920 and 1928 when 3,553 and 2,323 entered respectively. Between 30 and 35 percent of the total appear to have been female, although the sex ratio was more equal after 1917 than before. ${ }^{30}$ The major cause for greater immigration after 1917 was probably the termination of Indian immigration for all practical purposes after 1916.

Conditions on the first voyages to Surinam were often very poor; on several voyages death rates were high (64 out of 614 immigrants in 1894). Upon arrival in Surinam, the indentured Javanese was assigned

28. Waal Malefijt, Javanese of Surinam, p. 29. Professor Waal Malefijt relates the following story as typical of a Java-born informant: "One day on my way back from the neighboring city I met a stranger on the road and we began to talk. First he asked me questions about the rice crop or about what I had been doing in the city. Then he asked me if I would not like to earn a lot of money. When I asked him how, he told me that he could arrange for me to work in another country for a couple of years where I would be we11paid, so that I could return to my desa as a wealthy man. I told him that I could not leave my family. Then the stranger stepped on my foot, mumbling a spe 11 in a strange language, and sudden1y I no longer remembered having a family. So then I said 'All right, I will go to that country.' The stranger then brought me to a depot where many other Javanese were waiting. After some time there were enough of us to fill a ship. We received a metal tag with a number on it which we had to tie around our neck, and then we went aboard. When the ship was only a few yards from the shore I remembered everything. (The magic only worked on Java.) I wept, and everyone else wept, but it was too late."

29. Ismae1, Indonesia Pada Pantai, p. 42 .

30. Ibid., pp. 29-31. There were severa1 Sundanese but they were soon merged into the Javanese group. Ismael reports also finding one Minangkabau and one Atjehnese. Ibid., p. 33. 
to a plantation. The indenture contract was for five years. It lacked any provision for penal sanction because the Surinam Government felt the Javanese would be too far from home to run away. Both transportation to Surinam and free return to Java on completion of the indenture were guaranteed. The laborers were to have a six-day work week of eight to ten hours per day, with a daily wage, free housing and medical care. It was permissible to bring one's family, and wives and children were also paid wages. ${ }^{31}$

For the Javanese, life on the plantation in Surinam left much to be desired. Indications are that the mistreatment of laborers was far from uncommon and that cases of brutality by overseers existed as late as 1915. The isolation of plantations made it difficult for the government to check complaints, and district officers were likely as not sympathetic to the planter. A serious language barrier existed; as late as 1909 , no one in the entire colony could speak to the Javanese in their own language, and few Javanese knew Dutch or Negro-English, Surinam's Zingua franca. ${ }^{32}$

Poor conditions notwithstanding, only 7,684 Javanese elected repatriation to Java between 1897 and $1938 .{ }^{33}$ The majority remained, either working on the declining plantations as free laborers, working part-time and cultivating their own small plots part-time, or setting up as smallholders. There are several reasons for the decision of most Javanese to remain. After 1895 , the indenture contract stipulated that, after completion, all who desired would be allotted by the government a small plot of 1 and and a premium of 100 guilders in place of repatriation. From the perspective of those Javanese who had hoped to return home wealthy, Surinam did not prove a bonanza. The wages paid were not sufficient to allow any savings, particularly since living costs were much higher in Surinam than in Java. It was therefore probable that he would return to Java poorer than when he had left. Many feared ridicule and shame if they returned home penniless. Many Javanese had families in Surinam, others had acquired debts, and others were tired of waiting for available transportation. Some, especially women, feared another boat trip. Few chose to stay because they preferred Surinam to Java; the majority stayed because of bitter necessity, and this colored their attitudes toward their new home. ${ }^{34}$

The end of the indenture system in Surinam came slowly. The fact that so many immigrants remained in Surinam gave planters a labor reserve; many Javanese and some Indians worked on the plantations part-time or full-time. Slowly a wage economy emerged. Several thousand free immigrants came from Java in 1930, 1931, 1939,

31. Ismael, "De positie van de Indonesier," p. 180; Heemstra, "De Indonesiers in Suriname," p. 431; Waal Malefijt, Javanese of Surinam, pp. $25-26$.

32. Kloosterboer, Involuntary Labour, p. 35.

33. See Ismae1, Indonesia Pada Pantai, p. 31 .

34. See Waal Malefijt, Javanese of Surinam, pp. 27-31; van der Kroef, "Indonesian Minority," p. 674. 
and 1940 , most settling on or near plantations. ${ }^{3}$ The Depression, by spurring the decline of plantations, also encouraged the growth of kleine Zandbouw (small-scale agriculture) which did not use compulsory labor. In any case, labor conditions were improving in the $1920^{\prime} \mathrm{s}$ and $1930^{\prime} \mathrm{s}$; by 1931 indentured 1 abor had been ended in the Outer Islands of the Dutch East Indies, and international pressure was being exerted against forced labor. The Surinam government quiet1y terminated indentured 1 abor, no more importation being allowed after 1931. World War II ended immigration from Indonesia.

Javanese emigration to Malaya was less well-organized though no less regulated. Javanese had been recruited for Malaya in the nineteenth century, often through the Chinese Protectorate in Singapore. In addition, Indonesian sjech engaged in inter-island trading brought to Singapore many orang tebusan (mortgage men) from Java; these redeemed their passage money by working for employers specified by the sjech. ${ }^{36}$ But these immigrants probably never exceeded several thous and at one time. After 1902, Malayan planters received permission to import large numbers of Javanese laborers. An estate desiring Javanese workers would petition (through certain firms in the Straits Settlements or European companies in Java) the Netherlands Indies Governor-General via the office of the Penang or Singapore Consul. Private recruiters then handled the actual procurement. Contracts were generally for three years, and included housing, a food allowance, wages about equal to those of Indians but less than for Chinese, and generally a provision for repatriation. Although the contract specified a six-day work week, there were violations of the "spirit" of the law; Labour Commission reports in 1910 detail such malpractices as denying a day's pay for work unfinished and inducing workers to 1 abor on the rest day. ${ }^{37}$

Although the Javanese never became a major portion of the tota1 work force, which remained heavily Chinese and Indian, they did come in increasing numbers. In 1891, 14,239 Javanese lived in the Straits Settlements and Federated Malay States. Javanese made up over 70 percent of the total "Indonesian" population, and they were predominantly estate laborers. ${ }^{38}$ After 1902 the Javanese population increased rapidly; by 1931 the census reported 169,311 Javanese in Singapore, Johore, Selangor and Perak, said to be 90 percent of all the Javanese in Malaya. The Javanese had a strong tendency to settle permanently. The sex ratio before World War II is unknown, but it likely improved from 1901, when fewer than one-third were females. ${ }^{39}$

35. Heemstra, "De Indonesiers in Suriname," p. 432.

36. S. Husin Ali, Social Stratification in Kampong Bagan (Singapore: Malaysian Branch Royal Asiatic Society, 1964), pp. 29-32.

37. R. N. Jackson, Immigrant Labour and the Development of Malaya 17861920 (Kuala Lumpur: Government Press, 1961), pp. 127-129; Parmer, Colonial Policy, pp. 110-111; Shamsul Bahrin, "Indonesian Labour," pp. 65-67.

38. Shamsul Bahrin, "Indonesian Population," pp. 271-275. Sumatrans were not generally included in the "Indonesian" group. See also Bahrin, "Indonesians in Malaya," (Unpub1ished thesis, University of Sheffield, 1964), which was unavailable to me.

39. De1 Tufo, Malaya: 1947 Census, p. 74 ; Shamsul Bahrin, "Indonesian Population," p. 272. Another source reports 170,000 Javanese in 
The percentage of Javanese working on the estates appears to have declined in the twentieth century as more and more took up smallholding. The indenture system itself was abolished by the British authorities in 1932. Even by that time, the great majority of Javanese immigrants were free immigrants seeking to take up smallholdings. Free Javanese immigration was especially strong in the 1930's; in 1937, for example, 15,000 Javanese entered Malaya, largely to plant rubber. Evidently many Javanese, even those settled for many years, maintained contacts with their home villages and urged friends and relatives to join them. Indeed, to escape high recruiting costs, planters often encouraged this. Burridge studied a Javanese coffee-growing village in Johore, where former indentured laborers settled and then brought in relatives from Java. ${ }^{40}$ This immigration was warmly welcomed by Malayan authorities. Javanese immigration continued during the Japanese Occupation but in a way totally unexpected. Japanese authorities conscripted thousands of Javanese for forced labor throughout Southeast Asia, including Malaya. The number of survivors who remained in Malaya is impossible to confirm, and little data exists on these romusha. Generally, romusha were recruited in much the same way as contract labor--by fair means or foul--and reflected the labor surplus in Java. The horrors of their lives as "economic soldiers" were of course much worse than expected. ${ }^{41}$

Javanese settlement patterns in Malaya reflect their former estate ties. According to the 1947 census, there were 187,755 people who classified themselves as Javanese, including 163,040 in Malaya proper and 24,715 in Singapore. Those in Malaya lived primarily in Johore $(79,502)$, Selangor $(53,859)$, and Perak $(17,260)$, especially along the west coast of Johore and Perak and in the interior of Selangor. ${ }^{42}$

The Javanese immigrants to New Caledonia never approached in number those entering Malaya or Surinam; nonetheless, they played a more important economic role than in Malaya. The labor force needed in New Caledonia was smaller and conditions were apparently considerably worse than in Malaya or Surinam. Dutch officials were aware of this, and restricted importation of Javanese.

The 600 Javanese imported in 1902 were soon joined by others, so that by 1911 there were about 1,200 in the island. By 1929, the Javanese contingent numbered about 7,000 , but the Depression caused over half to return home. By 1939, however, the Javanese population had risen again to nearly 8,000 . Most of the Javanese were assigned to mines, plantations, or to work as domestic servants. By 1945 , for

Malaya in 1930. Soedigdo, Kebidjaksanaan Transmigrasi, p. 44.

40. Thompson, Labor Conditions, p. 78 ; Parmer, Colonial Policy, p. 112; Burridge, "Racia1 Relations," pp. 171, 181.

41. Shamsul Bahrin, "Indonesian Population," p. 272. See also fn. 8 above.

42. De1 Tufo, Malaya: 1947 Census, pp. 286-287; A. B. Ramsey, "Indonesians in Ma1aya," Journa1 of Ma1ayan Branch Roya1 Asiatic Society, 29 , no. I (May 1956), pp. 119-121. 
example, of the 7,249 Javanese residents, 6,264 men and women were employed as miners, rural laborers and servants. ${ }^{43}$ Most of the rest were probably children. Most Javanese imported in the pre-war years were repatriated, although some did sign on for second contracts, and some decided to remain indefinitely or permanently.

Contract labor in New Caledonia was enforced by penal sanction, which meant that a disrespectful remark to an overseer or escape from work (évasion) could be punished by fines and imprisonment. Contracts were for five years, but little money could be saved after food, lodging, and medical expenses and repatriation dues had been paid. Food served in the mines was often spoiled, and housing was makeshift. Two hundred people of both sexes and all ages were generally cramped into one building, and privacy, let alone proper sanitation, was out of the question. Working conditions in the mines were so notorious that in 1942 , the Dutch Consul protested strong1y against the inhuman conditions for Javanese miners at a nickel smelter near Noumea, where hours and conditions were considered far below international standards.

The periodic visits by Dutch inspectors were of 1ittle help in improving the situation, for the workers feared reprisals if they complained in front of French mining officials. The result was continued labor unrest and group action. Strikes were common, particularly in the early years of World War II. Planters complained that conditions were often dangerous, and it was said that "an unfortunate white man who finds himself before fifty or sixty Javanese or Tonkinese risks his skin each time they go on strike." 44 The French system in New Caledonia left much to be desired.

The tensions resulting from this system came to a climax in 1942 , with the beginning of the American occupation of the island. The generosity of the Americans greatly impressed the Javanese and Tonkinese workers. Those working for the Americans received liberal wages. At the same time, the French Government decided unilaterally to renew indentures, most of which were expiring. This precipitated a mass exodus of Asians to American camps for safety, causing a promulgation of mesures de répression to halt the exodus. Early in 1944, most Tonkinese declared a general strike which spread throughout the island. Later, the Javanese joined the movement. The French authorities capitulated and agreed to abolish indenture and to allow "free residence" to all Asians who desired it." 5 After the war, all but about 3,000 Javanese were repatriated, the remainder settling permanent $1 y$.

Not surprising1y, Javanese society in the three quite dissimilar environments of Surinam, New Caledonia and Malaya, developed in rather different ways. The Javanese of Surinam present a picture of strong cultural conservatism and resistance to integration. 46

43. Naval Intelligence Division, Pacific Islands, 3 (London: Great Britain Naval Staff, 1944), p. 450; Bruno Lasker, Human Bondage in Southeast Asia (Chapel Hill: University of North Carolina, 1950), p. 373.

44. Quoted in Feuer, "End of Coolie," pp. 265-266.

45. Ibid., pp. 265-267. See also Lasker, Human Bondage, p. 373.

46. Unless otherwise cited, information on the Surinam Javanese is 
Surinam has a tradition of "pluralism" that seems to encourage conservatism within each ethnic group; even Surinam's Indian, Chinese and African populations are considered more traditional than their counterparts in Guyana and other Caribbean countries with similar ethnic and historical foundations. Unlike either in Malaya or New Caledonia, in Surinam the Javanese make up a major segment of the population. Because nearly 80 percent settled permanently, the Javanese numbered 35,000 or approximate $1 y 21$ percent of the population by World War II, 4 and 43,000 , or 16.3 percent, by 1959 . On $1 y$ the Creoles (former African slaves) and Indians are more numerous, while European, Chinese, Bush Negro and Amerindian groups are much smaller. Javanese are especially strong in Commewijne $(12,225$ or 65 percent of the district), Suriname $(15,000$ or 18.3 percent) and Saramacca $(3,500$ or 31 percent $),{ }^{48}$ where they are largely sma11holder rice-growers.

The vast majority of Surinam's Javanese still live in rural areas. Only 11 percent live in towns as laborers, merchants, domestic servants or unemployed. ${ }^{49}$ The great majority of Javanese settlements are based on rice farming, supplemented by fishing and growing fruits and vegetables. Among these are some in which part-time plantation work is also important. Some Javanese still live and work exclusively on the plantation. While a few villages are homogeneous, most include non-Javanese inhabitants, although this rarely implies social integration. 50 Indeed, the Javanese, on the bottom of the socio-economic scale, are scorned by the Creoles whom they replaced on the plantations. In the eyes of the Creoles, the Javanese were "fools" to accept the kind of work the Creoles had done as slaves. Creoles and others express their prevailing sentiment toward the Javanese by such Negro-English expressions as "Zau-Zau Japanesi" ("stupid Javanese") and "Kan, sang joe sabi joe kong dja nanga karta joe neckie" ("Man, you don't know anything; you came here with a card around your neck"). ${ }^{51}$

The generally low socio-economic position of the Javanese is both symptom and cause of the relative isolation of the group, and this has contributed to the persistence of traditional culture. Indeed, the Javanese have made little attempt to adapt their traditional culture to Surinam society. One aspect of this is public disapproval of any interest in social mobility or the accumulation of material wealth, which is said to mean forsaking the Javanese heritage.

taken from Ismael, Indonesia Pada Pantai; and Waal Malefijt, Javanese of Surinam.

47. van Lier, Samenleving in een grensgebied, p. 255.

48. D.B.W.M. van Dusseldorp, "Geografische mobiliteit en de ontwikkeling van Suriname," Bijdragen tot de Taal-, Land-en Volkenkunde, 119 , no. 1 (1963), pp. 54-55.

49. Ibid., p. 39 .

50. See also G. D. van Wengen, "De rijstbouw bij de Javanen in Suriname, een veranderend cultuurpatroon," Nieuwe West-Indische Gids (1966), pp. 66-76.

51. Quoted in van der Kroef, "Indonesian Minority," pp. 674-675. 
The longing to remain Javanese while uncomfortably watching Indians, Creoles and others strive for a better material life results in insecurity, dissatisfaction and restlessness, manifested in the widespread nostalgia for Indonesia, and a disinterest in progress.

The desire of many to return to Indonesia was expressed in the $1930^{\prime} \mathrm{s}$ by a large Javanese following for a radical and messianic Creole agitator named DeKom who spread rumors that al1 Javanese would be allowed repatriation without cost.52 After the War, a political party called Persatuan Kaum Tani Indonesia (Indonesian Peasants' Union) was formed which promised to fight for repatriation. It had great success among Javanese peasants, and did succeed in repatriating 1,000 in $1954 .{ }^{53}$ In recent years it has been able to accomplish little, however, and its popularity has slackened. The widespread feeling of having been "tricked" into coming to Surinam, aided by a hope, particularly among the older generation, of an eventual repatriation, contributes to the close internal cohesion of the Surinam Javanese.

Javanese arts such as the wajang and gamelan flourish in Surinam and traditional celebrations including the slametan are important. Javanese and Bahasa Indonesia continue to be the major languages for all members of the community; very few know Dutch although more, particularly children, have learned some Negro-English. Harmony and cooperation are held as high ideals. Marriage into other ethnic groups is unusual and discouraged; when it occurs, it generally means rejection by the community.

Most Javanese appear to be generally abangan in religious orientation, but in each community there is a small group of generally older men acknowledged to be santri; they are widely respected by all, and it is from this group that the $k a^{\prime} u m$ (local religious leader) is chosen. ${ }^{54}$ In strong contrast to modern Java, no antagonism exists between santri and abangan elements. Indeed, they are complementary: the ka'um and santri provide a socio-religious framework and the abangan institution of the slametan gives content to the Javanese community. There are also a few Christians, slightly less than two percent. For the most part, relations between Muslim and Christian are good. 55

Despite the clinging to tradition, there is some evidence of change in the Javanese community. The younger generation manifests a diminished

52. See van Lier, Samenleving in een grensgebied, pp. 369-381.

53. Most of these 1954 repatriates were settled in Sumatra as transmigrants. For the story of this colony see H. J. Heeren, Het land aan de overkant (Meppe1: J. A. Boom en Zoon, 1967), pp. 106-132.

54. For a discussion of Javanese religious patterns, see Clifford Geertz, The Religion of Java (Glencoe: Free Press, 1960).

55. See also Annemarie de Waal Malefijt, "Animism and Islam Among the Javanese in Surinam," Anthropological Quarterly, 37, no. 3 (July 1964), pp. 149-155;'J. Prins, "De Islam in Suriname! een orientatie," Nieuwe West-Indische Gids, 41 (1961-1962), pp. 14-37; G. D. van Wengen, "Tajoeb, een prestige-feest bij de Javanen in Suriname," Bijdragen tot de Taal-, Land- en Volkenkunde, 119, no. 1 (1963), pp. 106-121. 
interest in Indonesia, and more willingness to participate in Surinam politics. In certain instances, Javanese culture seems to have been reinterpreted; despite the emphasis in Java on status differentiation, for example, Surinam's Javanese equate the maintenance of their "traditional" culture with the attempt at suppressing status differences.

The expectation that education will be an integrating force, as it is in Malaya and New Caledonia, has shown no sign of fulfillment. In Surinam, most Javanese children receive only a few years of schooling and the Javanese community remains ambivalent toward education. The schools teach in Dutch, a language few Javanese understand, and the attendance rate is very low. At present, the Javanese in Surinam are caught in a dilemma not faced by those in Malaya or New Caledonia. At the bottom of the socio-economic scale, they feel inferior, exploited, and threatened by the progress of other groups. In defense, they strongly emphasize what they have. De Waal Malefijt writes: "They are the only thing they can be: Javanese."56

Javanese society as it developed in New Caledonia came increasingly to be centered in an urban milieu, in contrast to Surinam. When indenture ended in 1946, nearly 3,000 Indonesians, the overwhelming majority Javanese, elected to remain. Most moved to the capital and largest city, Noumea, from which they had been excluded in the past. The 1963 census showed that 1,991 Javanese, or about 55 percent of the total Javanese population, lived in Noumea. ${ }^{7}$ The urban Javanese were able to move into positions vacated by the departing Japanese. Other Javanese communities can be found dispersed throughout the island, although their areas of highest concentration outside of Noumea are the districts of Hienghene and Thio, on the east coast. The 1956 census enumerated 2,889 Indonesians; by 1963 , this number had grown to 3,563 , or 4.1 percent of the population of New Caledonia. ${ }^{58}$

The New Caledonia Javanese can be found in a variety of occupations. Thirty percent are engaged in agriculture, primarily the growing of coffee, particularly as tenant farmers. On1y three percent have remained in the mining industry. In Noumea and the towns, Javanese are concentrated in construction and public works, commerce, manufacturing industry and services. Some Javanese appear to have entered the middle class but the majority are working class. 5 Alice Dewey notes that in Noumea no Javanese are wealthy but none are destitute.60 They are thus better off economically than those in Surinam, both in absolute terms and also in relation to other ethnic groups in the society. This is something of a paradox when seen

56. Waal Malefijt, Javanese of Surinam, pp. 187-192.

57. W. D. McTaggart, "Noumea: Capital of New Caledonia," South Pacific Bulletin, 16, no. 4 (1966), p. 44 .

58. Analyses des resultats 1963, p. 17.

59. Ibid., p. 41; Le Borgne, Nouvel1e-Calédonie, p. 170; Jean Guiart, "Noumea, New Caledonia," in Alexander Spoehr, ed., Pacific Port Towns and Cities: A Symposium (Honolulu: Bishop Museum, 1963), p. 30 .

60. Dewey, "Noumea Javanese," p. 22. 
against the notorious history of labor exploitation on the island.

Except for a handful of Chinese, the New Caledonian population of Tonkinese, Melanesian, European, Japanese, Polynesian, Indian and other Pacific Islanders was quite foreign to the Javanese. Information on Javanese society largely concerns the Javanese in Noumea, and those in areas such as Hienghéne are said to be much more traditional in orientation than in the Westernized, French-dominated capital. ${ }^{2}$ Nonetheless, provincial towns are also characterized by a société métisse much like that of Noumea, and Javanese in these areas may share the somewhat cosmopolitan urban culture of Noumea. ${ }^{62}$

As immigration has slowed to a trickle, the Javanese will soon be a largely local-born group. The 1963 census established that 57 percent of the Javanese were island-born. ${ }^{63}$ According to 1956 census figures, a smal1 but not insignificant number of Javanese were opting for French citizenship. ${ }^{64}$ Nonetheless, the Javanese community retains many elements of traditionalism. The Javanese are a distinct community, held together by language, religion and culture. The great majority are from Central Java; even those who are is 1and-born usually know Javanese, and some know Bahasa Indonesia as we11. Noumea's Javanese retain a strong taste for Javanese classical music, dance, art and the wajang, which are regularly presented at celebrations; the survival of the wajang has done much to maintain the Javanese way of life in Noumea. Celebrations, including the slametan, are common leisure time activities and provide much of the community structure not supplied by clubs and coffee shops. The pride taken in the achievements of modern Indonesia is evident from the fact that many listen to radio broadcasts from Indonesia and celebrate its independence day.

The religion of Noumea's Javanese appears to be largely abangan in orientation, possibly even more so than in Surinam. There are no mosques or formal Muslim services in New Caledonia and most of the ritual observances seem to be essentially Javanese. A small number of Javanese are Roman Catholic, but there is little tension between Christian and Muslim. The antagonism between 1ocal- and foreign-born, so common in immigrant groups, seems to be unimportant in Noumea. The strong Javanese value of group harmony is important.

While retaining many traditional elements, the Noumea Javanese have been in many ways more open to change than those in Surinam. Most Javanese children attend French schools with children from all ethnic groups, and almost all Javanese can speak some French, including recent adult immigrants. Javanese live dispersed throughout the city and no distinctive "Little Java" seems to have emerged; as late

61. Unless otherwise cited, the discussion which follows on Noumea Javanese culture is taken from Ibid., pp. 18-23, 26; and Dewey, "Restructuring Roles," pp. 38-51.

62. See P. H. Curson, "The Sma11 Urban Settlement in New Caledonia," South Pacific Bulletin, 15, no. 2 (April 1965), p. 24 .

63. Analyses des resultats 1963 , p. 26 .

64. Guiart, "Noumea," p. 26. 
as 1964 there was not even as yet a Javanese community center or voluntary association. Some intermarriage with other ethnic groups does occur; indeed, this was common before World War II.65 Most Javanese work at jobs which entail close contact with other groups.

Leadership structure within the Noumea Javanese community seems almost nonexistent. Status differences seem relatively unimportant, although wealthier individuals are often consulted on activities. Yet, if prominent people have some influence, they seem to 1 ack power. Because there are no village-maintained roads, irrigation systems, and the like, unlike Java, Malaya and Surinam, there is no need for a strong position of authority. For the same reasons, cooperative labor (gotong rojong) is absent. Kinship is also different, for few Noumea families have kin ties beyond spouse and children.

Turning to the Malayan case, it appears that in most respects the Javanese have been absorbed rather easily into Malay sociopolitical structures. ${ }^{66}$ It was not uncommon, however, for them to have their own villages and headmen in areas where they were sufficiently numerous, and relations with Malay villages have not always been cordial. Peter Wilson reports that the Malay villagers of Jendram Hilir in Selangor have nothing but contempt for the wholly Javanese village of Sungei Buah, only four miles away. According to the Malays, the Javanese there are dirty and therefore visiting was unpleasant, the Javanese are hard-working like the Chinese (and thus kasar, crude), and, al though Muslims, the Javanese occasionally eat pork, and have different customs (adat). Because of these "defects," marriage to a Javanese is definitely frowned upon. ${ }^{7}$ On the other hand, Burridge reports that some Javanese inhabitants in a Johore Malay village are highly respected and have a close relationship with the Malay leadership. ${ }^{6}$

This village or kampong settlement pattern in which villages are often entirely Javanese differs both from Surinam, where Javanese leaving the plantations moved into ethnically heterogeneous villages, and from the predominantly urban pattern established in New Caledonia. But despite the settlement pattern, the tendency seems to be toward eventual assimilation into the dominant Malay

65. See Burchett, Pacific Treasure Island, p. 148.

66. Data on Malayan Javanese culture is limited, and no field study comparable to Surinam exists. The following discussion is compiled from sources which touch on the Javanese, chiefly, unless otherwise cited, Ramsey, "Indonesians in Malaya," pp. 119-122; Ali, Social Stratification, passim; Burridge, "Racial Relations," pp. 153-181; Burridge, "The Malay Composition of a Village in Johore," Journal of Malayan Branch Royal Asiatic Society, 29, no. 3 (August 1956), pp. 60-77; David Radcliffe, "The Peopling of U1u Langat," Indonesia, 8 (October 1969), p. 166; Peter Wilson, A Malay Village and Malaysia (New Haven: HRAF, 1967), pp. 20-22; Judith Djamour, Malay Kinship and Marriage in Singapore (London: University of London, 1965), pp. 28, 60, $71-72,94-96,108,122$.

67. Wilson, Malay Village, p. 21.

68. Burridge, "Malay Composition," pp. 60-77. 
group. Children of Javanese parents generally attend Malay schools. ${ }^{69}$ Some Javanese have married non-Javanese and the barriers to assimilation are not strong, because of similar religion and language, in comparison to those faced by Chinese and Indians. A Johore Malay village studied by Syed Husin Ali was actually a Javanese village, settled in the late nineteenth and early twentieth centuries, whose inhabitants seem to have become "Malay" for all intents and purposes.70 At least in Johore, Javanese seem more inclined than Sumatrans to cut their ties with their homeland. The common threat posed to all Malay peoples by the growing Chinese population is not lost on the Javanese, and by promoting a common interest between Malays and Indonesian immigrants, encourages closer cooperation between the groups. Even highly-acculturated Javanese in Malay settlements, however, often have practices slightly different from Malay custom in such matters as kinship terminology, kin-group rank and status, adoption, and circumcision.

Little information is available on the occupations of the Javanese. Evidence from a variety of sources seems to indicate that most are sma11holder agriculturalists, growing rice, rubber, coconuts and vegetables. Javanese villages have a reputation for being progressive by Malay standards, and the Javanese is considered a hard worker, in contrast to the normal stereotype accorded the Malay. The 1947 census shows "Indonesians," of whom the Javanese are an overwhelming majority, largely engaged in agriculture, with civil service and armed forces being next in importance. Indonesians in Singapore are semiskilled workers, postal employees, and policemen. ${ }^{71}$

Despite the apparent trend toward eventual assimilation, the Malayan Javanese have retained much of their identity. C. A. Vlieland, in his report on the 1931 Malayan census, reports that whereas immigrant Sumatrans invariably classified their children, and often themselves, as "Malay," with al1 the privileges that classification entailed, most Javanese insisted on enumerating themselves and their children as Javanese. ${ }^{72}$ Whether this remains true today is not known, but the Javanese do retain their identity through their language; Javanese is still spoken in the home in most areas. In Selangor, for example, David Radcliffe visited in 1967 a Javanese village in Ulu Langat settled about 1916 in which the inhabitants still speak Javanese rather than Malay. ${ }^{3}$ Javanese immigrants in Johore are said to speak their own language among themselves although they also know Malay.

69. For the implications of the Malay school in the "making of the Malay," see David Radcliffe, "Education and Cultural Change Among the Malays 1900-1940," (Ph.D. dissertation, University of Wisconsin, Madison, 1969).

70. Ali, Social Stratification.

71. De1 Tufo, Malaya: 1947 Census, p. 106; Hodder, "Racial Groupings in Singapore," pp. 31-33; A Social Survey of Singapore (Singapore: Department of Social Welfare, 1947), pp. 51-52.

72. C. A. V1ieland, British Malaya: A Report on the 1931 Census (London: H.M.S.O., 1932), p. 75. In 1947, even the Malaya-born registered as' Javanese in large numbers. De1 Tufo, Malaya: 1947 Census, pp. 286-287.

73. Radcliffe, "Ulu Langat," p. 166. 
Elements of traditional Javanese culture which persist in Malaya today include the importance of magic and power, particularly as invested in the village headman, and the deference accorded to highstatus individuals such as the headman; it is said that, until recently, older Javanese would crouch in obeisance at the side of a road when a social superior passed by. Headmen are reputed to have strong authority; this may be partially a result of the nature of the migration process, which seems to have been characterized by family or village group migration to a greater extent than was the case in Surinam and New Caledonia. This was partially a consequence of the policy of many Malayan planters to encourage settlers to write to friends and relatives in Java, asking them to join those already in Malaya; this was of course made more feasible because of relative geographical proximity. It should be noted that this emphas is on authority and deference to authority, which seems to have remained important among the Malayan Javanese, is in contrast to the stress on equality among those in Surinam. The latter phenomenon may be a function of the disadvantaged position in which the Surinam Javanese have found themselves.

Information on the religion of Malayan Javanese is sketchy at best and often contradictory. On the one hand, we are told that Javanese have been more inclined than Malays to make the pilgrimage to Mecca, especially in the 1920's and 1930's, although this interest seems to have waned somewhat in recent years. ${ }^{4}$ Arabic schools and mosques were also common in Javanese villages. This could imply a commitment to a more santri orientation. On the other hand, the popularity of magic, and the predominantly peasant culture, suggest abangan tendencies. Unfortunately we can on $1 y$ speculate; we do not even know whether slametan occur in Malaya. It is not unlikely that both santri and abangan elements exist in Malaya, for the Javanese there seem to come from diverse origins. It is possible that santri practices may be more widespread in Malaya than in Surinam or New Caledonia not only because of Malay Muslim influence but also because a larger number of Malayan Javanese may have come from the pasisir, north shore of Java, for example the bonded laborers brought by the sjech.

This cursory examination of the overseas Javanese has shown certain general similarities among the emigrants. The common denominator for emigration was poverty or personal problems. The majority went overseas as indentured laborers, although a larger number of free emigrants went to neighboring Malaya; once arrived, a large number elected to remain permanently or semi-permanently. In Surinam and Malaya the great majority remained in agriculture; only in New Caledonia (and Singapore) has an urban--but largely non-commercial-group been established. A marked cultural conservatism is noticeable, but this is not, of course, unusual among overseas Asians or indeed among other immigrant groups.

The Javanese is quite different, however, from his Chinese and Indian fellow-emigrants, despite an often common heritage of contract labor, in that he has not in most cases gone into commerce. The Javanese are still in agriculture, whereas the Chinese are largely in trade, whether in Malaya, New Caledonia, or Surinam. The Indians are somewhat closer to the Javanese pattern, as a great number are

74. Ramsey, "Indonesians in Ma1aya," p. 122. 
still in agriculture, although again a much larger number have gone into business or other urban occupations than is true for the Javanese. But there are also important differences between rural Indians and rural Javanese, though it varies from area to area. In Malaya, the rural Indian is much more likely than the Javanese to be an estate laborer rather than a smaliholder. ${ }^{75}$ This is at least in part a consequence of the greater percentage of Javanese who went to Malaya as free immigrants. The situation in Surinam is reversed, with a greater percentage of Indian smallholders than Javanese. Since there was little free immigration to Surinam, the Indians and Javanese arrived in much the same way, the major difference being that the Indians arrived earlier and thus got a headstart in leaving the plantations and taking up smallholding. Indeed, the earlier arrival of both Chinese and Indians in all three countries made it possible for them to develop an earlier foothold off the estates. Perhaps those Javanese who emigrated were also less inclined, or less we 11 prepared, to go into commerce.

The gaps in our knowledge of the Javanese emigrant are readily apparent. The Malaya Javanese definitely merit a field study to supply more information on culture, religion and Malay-Javanese relations. The nature of Javanese rural life in New Caledonia and the small urban group in Surinam is at present largely unexplored. Finally, we need to know much more about the emigration process itself, especially for Malaya and New Caledonia, the background of the emigrants, and the nature of the recruitment system. The emigrant Javanese remain a challenge to social scientists interested in migration, social change and plural societies; they also direct our attention to a neglected theme in modern Indonesian history.

75. Sandhu, Indians in Malaya, pp. 273-274. 